\title{
Application of Parental Education About Social Media and Adolescent Sexual Behavior
}

\author{
$1^{\text {st }}$ Endang Wahyuningsih \\ Midwifery Department \\ STIKES Muhammadiyah Klaten \\ J1 Ir Soekarno Km 1 Buntalan 57419, \\ Klaten, Indonesia \\ endangwahyuningsih@stikesmukla.ac.id \\ $4^{\text {th }}$ Piscolia Dynamurti Wintoro \\ Midwifery Department \\ STIKES Muhammadiyah Klaten \\ J1 Ir Soekarno Km 1 Buntalan 57419, \\ Klaten, Indonesia
}

\author{
$2^{\text {nd }}$ Wiwin Rohmawati \\ Midwifery Department \\ STIKES Muhammadiyah Klaten \\ Jl Ir Soekarno Km 1 Buntalan 57419, \\ Klaten, Indonesia
}

\author{
$3^{\text {rd }}$ Astri Wahyuningsih \\ Midwifery Department \\ STIKES Muhammadiyah Klaten \\ J1 Ir Soekarno Km 1 Buntalan 57419, \\ Klaten, Indonesia
}

\begin{abstract}
Internet technology and social media have become increasingly widespread . Starting from the use of Twitter, Facebook, WhatsApp. The role of parents becomes very important to care about adolescent reproductive health than the opinions or delusions of adolescents themselves. Parents must provide time to get information and pay attention to their teenage children, especially in sexual behavior. This situation can cause alarming problems because it can cause an increased risk of premarital sex, teen pregnancy, mental unpreparedness, increased risk of malignant disease. the purpose of the study to determine the effect of counseling parents use social media to teenage sexual behavior .Research is using design quasy experiment with the design of a one-group pre - post testdesign. We got 3 6 teen respondents .the sample selected by the method of purposive sampling. The instrument that is used is the questionnaire. The results showed that 8 adolescents had good sexual behavior $(22.2 \%)$, less sexual behavior of adolescents decreased to 8 adolescents $(22.2 \%)$. Wilcoxon test results show that $p(0.022)(<0.05)$ which means there is an influence from parents, especially counseling on adolescent sexual behavior. This shows that sexual behavior in adolescents has decreased with the involvement of parents in providing counseling.
\end{abstract}

Keywords-Parents Education, Social Media, Adolescent Sexual Behavior

\section{INTRODUCTION}

[1]Adolescence is a fast period of development, growth and maturity phisically, psychologically, and socially. Phisically growth shown by the maturity of the body organs such as the reproduction organs and reproduction sexual hormons in the body. Beside that adolescence is the period that is full of emotion, full of acquintences and adventures of new things especially with the other gender. Todays phenomena is free sex behaviors. Free sex is the relationship that is caused by sexual desire both with the same gender and with the opposite gender.

[2]Adolescents need serious attentions and actions soon. This is because adolescence is the transition period which is easily influenced, in this period they need extraordinary assistance adolecent is a susceptible group because if an adolecent is out of supervision, he/she can involve in the wrong or negative things. But if an adolecent can optimize himself/herself, he/she will have a good personality and is ready to live his/her life.free sex is a way to intercourse that is done to a spouse, that is not married. [3] The factors that causes the changes of point of view to free sex to adolecent is caused by lack of attention and supervision from parents and family, free social intercourse, the free sex supporting enviroment, and the facilities given by family.

[4]Adolecent are the productive users of social media they spend most of their time to interact using social media.[5]Meeting online through website or dating online tends to early heterosexual marriage. [6] The social media will effect their aggresiveness, sexual behavior, eating disorder, and academic difficulties. This will effect parents who are worried about their safety and their social developement. Adolecents/teenagers are the biggest users of social media and more integrated to the other medias and online community.

[7]Electronic media is the centre of the fast sophisticated developement of modern technology. There are many positive dan negative things appeared with the development of technology. Adolescents/teenagers have the concentration to have high couriousity so that sometimes lack of parent's supervision makes them do negative things, like watching adult contents and listen to adult conversations through electronic medias. [8]Things wished by teenagers in using social media is the feedback from other users. They consider that the feedbacks of other users are the form of support or motivation. [8]They say that "like, comment, and follow back" are form of attentions and support. This is of course give bad effect to teenagers because they will feel more considered. This makes them feel more comfortable when communicating in social media, makes them more introvert.

It is reported that $50 \%$ of teenagers are the handphone users. They use the handphone to access social media such as Facebook, Line, WhatsApp, Instagram. So far parents 
still let them do that because they don't know the negative effects and even they don't control it.

\section{METHODS}

Our research design is quasy experiment. This research is one-group pre-post test design. Our samples are all parents that have children age 15-19 years old and understand social media. We get the 36 examples are use purpose sampling technique. We got the data by giving quisionair as a pretest step. Then we distribute quisionair to parents as the research respondents to observe their children in using the social media for a month. After that parents will do the pretest too. We analyze the data using the wilcoxon analysis data method.

\section{RESULTS}

Based on the result of this research are parents age 4160 years (23 persons) is 63,9\%. The education of the subjects are (SD,SMP-22 persons, the average is $70,1 \%$. And the occupations of the subjects are majority house wife, that is 19 with average $52,8 \%$. The age of the children are 16 and 17 years are 10 children, with the average $27,8 \%$. The result of this research shows that teenagers who have enough sexual behaviors before teh education is 17 with average $47,2 \%$. Meanwhile after the education with enough category is 20 wit average $55,6 \%$. The result of the education to parents about sosmed with good sexual behavior is teenagers is only 4 teenagers $(11,1 \%)$ that have poor sexual behavior is teenagers $(41,7 \%)$. Meanwhile after the education there is improvement. Teenagers who have poor sexual behavior becomes 8 teenagers $(22,2 \%)$. The result of wilcoxon analysis is $\mathrm{R}=2,295$ and $\mathrm{P}=0,022$. It means $\mathrm{p}<0,05$ shows the effect of the education to parents about sosmed and adolescent sexual behavior.

TABEL 1 COUNSELING PEOPLE ABOUT THE USE OF SOCIAL MEDIA AGAINT YOUTH SEXUAL BEHAVIOR

\begin{tabular}{lcccccc}
\hline \multirow{2}{*}{$\begin{array}{l}\text { Sexual } \\
\text { behavior }\end{array}$} & \multicolumn{2}{c}{ Pretest } & \multicolumn{2}{c}{ Postest } & Z count & p value \\
\cline { 2 - 5 } it & \\
\hline Good & 4 & 11,1 & 8 & 22,2 & 2,295 & 0,022 \\
Enough & 17 & 47,2 & 20 & 55,6 & & \\
Less & 15 & 41,7 & 8 & 22,2 & & \\
\hline & 36 & 100 & 36 & 100 & & \\
\hline
\end{tabular}

\section{DISCUSSIONS}

The result of our research shows that the age of th that children are involve in our reseach is in puberty period, 16 and 17 years old. Puberty period stars at the age of 8 till 10 and it ends at the age of 15 to 16 in which they undergo pkysical, psycological changesand their sexual functions becomes mature.[9]Someone's puberty is influenced by nutrition factors and audio visual simulants from outside. In my opinion, a good quality of nutrition given to children will fasten the hormon formation in the body. Sexual hormons that have been formed in the body then will be stimulated by audio visual stimulants from outside and will fasten the children's bioogical maturity. [10]The manarche age is influenced by electronic medias. [11]The technology for the sexual health risk reduction through facebook and whatsapp can build communication between the institution that provides information about teenage reproduction health and answering personal questions. [12]INCAR program aims to give information and counseling by their peers through PIK blogs, teenage community in ,facebook, whtsapp and instagram. The result of this reseach shows that teenagers who have enough sexual behavior is $17(47,2 \%)$ and after the education is $20(55,6 \%)$. It show that there is improvement and hopefully this will reduce the risks of free sexual behaviors. 920 sexual bahavior is all forms of behaviors that caused by sexual needs both from the same gender and theopposite gender. [2] This sexual behaviours starts from holding hands, hugging, kissing, touching yhe sensitive parts of the body untill penetrating the sexual organs. 920 sexual bahaviours influnced also by the religion( the decreasing of the belieft on religion), different genders, KB campaign, economic social factors( the low income and educational background), family attentions and self control.

Our subjects in this reseach are teenage parents aged 15-19 and the parents who becomes our respondent (age 41-60) are 23 persons. In my opinion, Age can influence someone's pontof view. The research shows that teh role of family especially parents are important in the development of children maturity. [13]And with the education to parents can give good effect to the children. [14]Meanwhile the subjects aremostly mothers andtheteenagers are mostly girls. It also shows that mothers usually can communicate well withtheirdaugthers. [15]Familyrole indeed is very important in preventing theteeagers from having bad sexual bahaviours.

\section{CONCLUSIONS}

Based on the result of the research, it can be concluded that sexual behavior is improved after the education. It shows that it is significant to give education to give education to parents about sosmed and sexual behavior. It is shown by the data analysis $p$ value $0,022(p<0,05)$. Based on the conclusion we suggest parents should do their best to educate their children and control their use of sosmed, improve the society awareness though various communication media information and education about adolescents reproduction health and using music shows and other creative media to give information to the adolescents and parents.

\section{ACKNOWLEDGMENT}

Thank you to the Chairperson of College of Health Sciences Muhammadiyah Klaten for providing the opportunity to carry out this research.

\section{REFFERENCES}

[1] A. Ediati, "Profil Problem Emosi/ Perilaku Pada Remaja Pelajar SMP-SMA Di Kota Semarang," J. Psikol. Undip, vol. 14, no. 2, 2015.

[2] Sarwono, Psikologi remaja. Jakarta: PT. Rajagravindo Persada, 2010.

[3] A. Pangkahila, Tumbuh Kembang Remaja dan Permasalahannya. Jakarta: Sagung Seto, 2014.

[4] J. Ahn, "Advance in Information Science The Effect of Social Network Sites on Adolescents," J. Am. Soc. Inf. Sci. Technol., 
vol. 62 No 8, pp. 1435-1445, 2011.

[5] M. J. Rosenfeld, "Marriage, choice, and couplehood in the age of the internet," Sociol. Sci., vol. 4, pp. 490-510, 2017.

[6] V. C. Strasburger, A. B. Jordan, and E. Donnerstein, "Health effects of media on children and adolescents," Pediatrics, vol. 125, no. 4, pp. 756-767, 2010.

[7] P. Wulandari, "Faktor-Faktor Yang Berhubungan Dengan Kejadian Menarche Siswi Di SMPN 31 Semarang," $J$. Keperawatan, vol. 6, Nomor 2, pp. 117-122, 2015.

[8] R. D. Pamela Felita, Christine Siahaja, Vania Wijaya, Gracia Melisa, Marcella Chandra, "Pemakaian Media Sosial Dan Self Concept Pada Remaja," J. Ilm. Psikol. MANASA, vol. 5, no. 1, pp. 30-41, 2016.

[9] Azwar, Sikap Manusia Teori dan Pengukurannya. Yogyakarta: Pustaka Pelajar, 2009.

[10] Y. L. R. D. Mirzawati Latifah, Bhisma Murti, "Effect of Soft Drink, Electronic Media Exposure, Family Income, Pocket Money, and Nutritional Status, on Age at Menarche Among Adolescents in Surakarta," vol. 2, pp. 54-63, 2017.

[11] I. P. Christoper Reynolds, Melissa A. Sutherland, "Exploring the Use of Technology for Sexual Health Risk-Reduction among Ecuadorean Adolescents," vol. 85, no. 1, pp. 1-10, 2019.

[12] A. G. Nurjaman, Rusman; Prasetyo, "Jurnal Borneo Administrator," J. Borneo Adm., vol. 14, no. 1, pp. 35-52, 2018.

[13] M. J. Prinstein, "NIH Public Access," vol. 51, no. 7, pp. 731741,2015

[14] J. B. Cornelius, C. Whitaker-Brown, T. Neely, A. Kennedy, and F. Okoro, "Mobile phone, social media usage, and perceptions of delivering a social media safer sex intervention for adolescents: results from two countries," Adolesc. Health. Med. Ther., vol. Volume 10, pp. 29-37, 2019.

[15] N. Longkutoy, J. Sinolungan, and H. Opod, "Hubungan Pola Asuh Orang Tua Dengan Kepercayaan Diri Siswa Smp Kristen Ranotongkor Kabupaten Minahasa," J. e-Biomedik, vol. 3, no. 1, 2015. 